STUDIA HISTORICA GEDANENSIA

TOM XII (2021)

\author{
Michalina Petelska \\ (Uniwersytet Gdański) \\ https://orcid.org/0000-0002-7436-3280
}

\title{
Polskie muzea w czasie pandemii COVID-19: działalność online i (nie)stosowanie Rapid Response Collecting ${ }^{1}$
}

Słowa kluczowe: Rapid Response Collecting, muzeum, pandemia COVID-19

Keywords: Rapid Response Collecting, museum, COVID-19 pandemic

\section{Wstęp: wyzwania i rozwiązania}

W trakcie pandemii każdy dział muzeum musiał rozwiązywać całkowicie nowe problemy. Czy da się pogodzić odkażanie pomieszczeń z właściwą opieką nad muzealiami? Czy i jak udostępniać wystawy stałe i czasowe? Jak organizować edukację muzealną $\mathrm{w}$ trakcie lockdownu? To tylko podstawowe $\mathrm{z}$ wielu nowych wyzwań. Na bieżąco wypracowywano rekomendacje ${ }^{2}$ i ogłaszano nowe regulaminy zwiedzania. Wielką kreatywnością wykazywali się muzealnicy odpowiedzialni za edukację, udostępnianie zbiorów oraz organizację wydarzeń i wystaw czasowych. Nadal bez odpowiedzi pozostają pytania dotyczące strategii długofalowych

1 Za dyskusję nad tekstem dziękuję dr. Grzegorzowi Labudzie, Głównemu Inwentaryzatorowi Zbiorów Muzeum Emigracji w Gdyni.

2 Przykładem takich rekomendacji są dokumenty opracowane przez specjalistów z Muzeum Narodowego w Warszawie: „Zabezpieczenie dzieł sztuki podczas odkażania pomieszczeń”, oprac. Dorota Ignatowicz-Woźniakowska (Główny Konserwator MNW), Laboratorium MNW pod kierunkiem dr Elżbiety Pileckiej-Pietrusińskiej, http://www.mnw.art.pl/aktualnosci/chronmy-dziela-sztuki-podczas-odkazania-pomieszczen,597.html, dostęp 14 VI 2021 r.; „Rekomendacje dla działań mających na celu ograniczanie możliwości rozprzestrzeniania się koronawirusa w sytuacjach związanych z udostępnianiem dzieł sztuki”, oprac. Dorota Ignatowicz-Woźniakowska (Główny Konserwator MNW), dr Elżbieta Pilecka-Pietrusińska (Kierownik Laboratorium MNW), Marcin Draniak (Laboratorium MNW), http://www.mnw.art.pl/aktualnosci/rekomendacje-dot-ograniczenia-mozliwosci-rozprzestrzeniania-sie-koronawirusa-przy-udostepnianiu-dziel-sztuki,609.html, dostęp 14 VI $2021 \mathrm{r}$. 
i zarządzania instytucjami muzealnymi. Niepewność muzealników wynika z sytuacji globalnej (epidemicznej, gospodarczej).

Opracowanie całości zagadnienia „muzea a pandemia” wciąż jeszcze jest wyzwaniem dla muzeologów. W niniejszym artykule poddaję analizie dwie sfery aktywności muzealników, aby szukać odpowiedzi na pytanie, jak polskie muzea towarzyszyły społeczeństwu $\mathrm{u}^{3} \mathrm{w}$ trakcie pandemii i jak dokumentowały jej przebieg. Odpowiedzi na te pytania mają także szerszy, uniwersalny wymiar, jak bowiem ukażą to podane przykłady - metody zastosowane w trakcie pandemii mogą być także wykorzystywane w innych sytuacjach.

\section{Rapid Response Collecting}

Czy można udokumentować pandemię za pomocą kolekcji i wystawy muzealnej? Istnieje już opracowana - i wypróbowana w praktyce - metodologia Rapid Response Collecting (dalej: RRC), co można przetłumaczyć jako strategię tworzenia kolekcji na zasadzie szybkiego reagowania. Początki RRC wiązane są z zamachami terrorystycznymi na wieże WTC w Nowym Jorku 11 września $2001 \mathrm{r}^{4}$ W USA RRC wykorzystywano także do dokumentowania innych zamachów, takich jak strzelanina w klubie nocnym Pulse w Orlando 12 czerwca 2016 r., w czasie której zginęło 50 osób ${ }^{5}$. W ostatnich latach RRC stało się także muzealną odpowiedzią na ruch Black Lives Matter (dalej: BLM) ${ }^{6}$. Jedno z najsłynniejszych muzeów świata, Smithsonian National Museum of American History, odwołując się do RRC, zbierało transparenty i inne obiekty wykorzystane podczas szturmu zwolenników Donalda Trumpa na Kapitol 6 stycznia 2021 r. ${ }^{7}$

RRC dotyczy nie tylko włączania obiektów do kolekcji muzeum, ale także organizowania wystaw prezentowanych w czasie, gdy omawiane na ekspozycji wydarzenia wciąż jeszcze trwają (lub bezpośrednio po nich). Sam termin Rapid Response Collecting i jego rozumienie związane $\mathrm{z}$ wystawiennictwem spopularyzowało

3 Pisząc o „towarzyszeniu społeczeństwu”, podążam za definicją muzeum ICOM z 2007 r., która podkreśla, że muzeum działa „na rzecz społeczeństwa i jego rozwoju”. Zob. Dorota Folga-Januszewska, „Dzieje pojęcia muzeum i problemy współczesne - wprowadzenie do dyskusji nad nową definicją muzeum", Muzealnictwo 61 (2020): 27-45.

4 Sandro Debono, „Collecting Pandemic Phenomena: Reflections on Rapid Response Collecting and the Art Museum", Collections: A Journal for Museum and Archives Professionals 17, issue 2 (2021): 2, https://doi.org/10.1177\%2F1550190620980844.

5 Pam Schwartz, Whitney Broadaway, Emilie S. Arnold, Adam M. Ware, „Rapid-Response Collecting after the Pulse Nightclub Massacre”, The Public Historian 40, issue 1 (February 2018): 105-114.

6 C. Ghiorsi Hart, „With Rapid Response Collecting, Who Are We Responding To?”, posted on Nov 23, 2020, American Alliance of Museums, https://www.aam-us.org/2020/11/23/with-rapid-response-collecting-who-are-we-responding-to/, dostęp 14 VI $2021 \mathrm{r}$.

7 Elisa Schoenberger, „Smithsonian Collects Artifacts from Insurrection”, Library Journal 146, issue 3 (March 2021): 17. 
cieszące się światową sławą muzeum sztuki i designu - Victoria \& Albert Museum w Londynie (dalej: V\&A Museum). W 2014 r. otwarto w nim nową stałą galerię, sukcesywnie uzupełnianą o kolejne obiekty. Kolekcja ta - choć po raz pierwszy udostępniona zwiedzającym w konkretnym roku - z założenia się nie starzeje, pozostaje bowiem aktualna poprzez dodawanie kolejnych muzealiów o sile symbolu. Obecnie na kolekcję składają się między innymi: dron z 2015 r., ulotka z referendum w sprawie Brexitu z 2016 r., czapka uczestniczki Women's March (protestu zorganizowanego $\mathrm{w}$ Waszyngtonie dzień po inauguracji prezydentury Donalda Trumpa) z 2017 r., konsola X-box z 2018 r. i logotyp Extinction Rebellion z 2019 r. ${ }^{8}$ Kuratorzy V\&A Museum podkreślają, że „każdy nowy nabytek porusza inną kwestię dotycząca zmian ekonomicznych, politycznych i społecznych, globalizacji, technologii i prawa" . Z kolei Aaron Bryant, kurator z National Museum of African American History and Culture (Washington DC, USA), podkreśla, iż „decydujące znaczenie ma to, że kolekcjonujemy, aby ten moment nie przepadł. Historia dzieje się na naszych oczach"10.

O czasie pandemii koronawirusa z całą pewnością również można powiedzieć, że historia działa się wtedy na naszych oczach. Wiele muzeów na świecie podjęło wyzwanie odzwierciedlania dramatycznych wydarzeń w tworzonych kolekcjach i wystawach. Projekty te są tak liczne, że mija się z celem próba wymienienia tutaj choćby reprezentatywnej ich części ${ }^{11}$. Jako przykład niech posłuży zatem bliski nam kraj w Europie Środkowej, dzielący z Polską wiele historycznych uwarunkowań rozwoju muzealnictwa. W czeskim Muzeum Narodowym (Národní Muzeum) w Pradze dostrzeżono, że nowym symbolem naszych czasów stała się maseczka ochronna. Od maja 2020 r. do czerwca 2021 r. prezentowano wystawę pod wymownym tytułem „Trzymamy się razem” („Držíme spolu”). W podtytule wystawy wyjaśniono, że stanowi ona pokaz masek, które weszły w skład kolekcji Muzeum. Różnorodność masek pozyskanych do jego zbiorów odzwierciedla różne fazy pandemii i różne sposoby radzenia sobie z sytuacją, charakterystyczne nie tylko dla Czechów. Były tam więc pierwsze maseczki szyte samodzielnie $\mathrm{w}$ domach, maseczki przekazane przez obywateli do jednego ze szpitali w początkach pandemii, maseczki stworzone przez znanych projektantów i te przygotowane

8 „Collection Highlights”, Victoria \& Albert Museum w Londynie, https://www.vam.ac.uk/ collections/rapid-response-collecting, dostęp 14 VI $2021 \mathrm{r}$.

$9,[\ldots]$ each new acquisition raises a different question about economic, political and social change, globalisation, technology and the law" (wszystkie tłumaczenia w tekście pochodzą od autorki artykułu), „Collection Highlights”, Victoria \& Albert Museum w Londynie, https://www.vam.ac.uk/ collections/rapid-response-collecting, dostęp 14 VI $2021 \mathrm{r}$.

10 „It is critical that we collect so this moment does not get lost. History is happening right before us”, Debono, „Collecting Pandemic Phenomena”, 2.

11 Można je śledzić nie tylko w sieci, ale również za pośrednictwem powstających publikacji naukowych, np. Sarah Laurenson, Calum Robertson, Sophie Goggins, „Collecting COVID-19 at National Museums Scotland”, Museum and Society 18, no 3 (November 2020): 334-336, https:// doi.org/10.29311/mas.v18i3.3519. 
specjalnie dla dzieci ${ }^{12}$. O ile powyższą wystawę można określić mianem skromnego pokazu masek - a więc tylko jednego rodzaju muzealiów - to równolegle zaprezentowano o wiele bardziej rozbudowaną wystawę, której osią była postać św. Korony, męczennicy z II w., której przypisywano przez wieki szczególne wstawiennictwo w czasie epidemii. Ekspozycja została opatrzona dwuznacznym tytułem „Korona w muzeum!” („Korona v Muzeu!”, grudzień 2020 r. - czerwiec 2021 r.). Łączyła ona wątki historyczne (dawne sposoby walki z chorobami zakaźnymi i rolę świętych patronów) oraz współczesne (pandemia koronawirusa) ${ }^{13}$. Czy i jak polskie muzea zrealizowały analogiczne projekty?

Na tle Polski wyjątkową aktywnością odznaczył się ośrodek krakowski, w którym aż dwa muzea zorganizowały „w czasie rzeczywistym” projekty związane z pozyskiwaniem obiektów do kolekcji i przygotowaniem wystaw. Już w marcu 2020 r. (!), czyli w miesiącu, w którym do Polski dotarła fala zakażeń koronawirusem, Muzeum Etnograficzne im. Seweryna Udzieli rozpoczęło badania ankietowe „Nasze życie w czasach zarazy”, których częścią było tworzenie „Kolekcji w kwarantannie”. Jak pisali sami organizatorzy, „Zapraszamy do współtworzenia zbioru przedmiotów i związanych z nimi opowieści. Kiedyś zaświadczą o sposobach radzenia sobie z dziwną rzeczywistością, w jakiej się znajdujemy" ${ }^{14}$. Powstała uzupełniana na bieżąco wystawa wirtualna, prezentująca zdjęcia obiektów związanych z pandemią ${ }^{15}$. Pracownicy Muzeum podkreślali również, że na podstawie badań i zbiórki zamierzają przygotować wystawę stacjonarną w samym Muzeum.

W kwietniu 2020 r. także Muzeum Krakowa zaprosiło krakowian do uczestnictwa w zbiórce związanej z pandemią. W pierwszym etapie zbierano „To, co można przesłać drogą mailową", ale już w tym pierwszym komunikacie zapowiadano, że gdy tylko sytuacja na to pozwoli, Muzeum będzie też organizować spotkania osobiste i przyjmować obiekty kultury materialnej ${ }^{16}$. Taką możliwość pojawiła się we wrześniu i październiku 2020 r. ${ }^{17}$ Efektem zbiórki - oraz pracy kuratora

12 „Držíme spolu. Výběr roušek, které se nově staly součástí sbírek Národního muzea”, Národní muzeum w Pradze, https://www.nm.cz/program/vystavy/drzime-spolu, dostęp 14 VI $2021 \mathrm{r}$.

13 „Korona v Muzeu! Výstava v Historické budově dokumentuje analogii jména světice a koronaviru a zasazuje ji do kontextu minulých pandemii", Národní muzeum w Pradze, https://www. nm.cz/program/vystavy/korona-v-muzeu, dostęp 14 VI $2021 \mathrm{r}$.

14 „Kolekcja w kwarantannie”, Muzeum Etnograficzne im. Seweryna Udzieli w Krakowie, https://etnomuzeum.eu/kolekcjawkwarantannie/o-kolekcji, dostęp 14 VI 2021 r.

15 „Kolekcja w kwarantannie wystawa online, którą możesz tworzyć razem z nami”, Muzeum Etnograficzne im. Seweryna Udzieli w Krakowie, https://etnomuzeum.eu/wystawy-czasowe/kolekcja-w-kwarantannie, dostęp 14 VI $2021 \mathrm{r}$.

16 „Opowiedz z nami o czasie pandemii. Informacje na temat zbiórki przedmiotów z pandemii”, opublikowane 10 IV 2020 r., Muzeum Krakowa, https://muzeumkrakowa.pl/aktualnosci/opowiedz-z-nami-o-czasie-pandemii, dostęp 14 VI $2021 \mathrm{r}$.

17 „Rozpoczynamy akcję zbierania przedmiotów związanych z pandemią! Informacje związane z akcją!”, opublikowane 1 X 2020 r., Muzeum Krakowa, https://muzeumkrakowa.pl/aktualnosci/ rozpoczynamy-akcje-zbierania-przedmiotow-zwiazanych-z-pandemia, dostęp 14 VI 2021 r. 
i zespołu Muzeum - jest wystawa „Współistnienie” (czerwiec 2021 r. - kwiecień 2022 r.). Tekst promujący wystawę na stronie internetowej Muzeum Krakowa można zacytować jako doskonałą ilustrację filozofii RRC: „Opowiedzieć pandemię, na dodatek w trakcie jej trwania - to wielkie wyzwanie [...] „Wspólistnienie” nie jest wystawą, jak inne, które w muzeum historycznym, miejskim opowiada się z pewnego dystansu [...] Praca jej twórców bliższa była pracy reporterów [...] to nie jest opowieść pisana w czasie przeszłym, dokonanym. To historia w czasie teraźniejszym - dzieje się tu i teraz. Będzie się działa także w trakcie trwania ekspozycji, dlatego zaplanowano jej aktualizacje"18.

RRC w muzealnej praktyce często bywa reakcją na protesty społeczne. Powyżej wymieniłam już ruchy BLM oraz Women's March. Praktyka RRC została wykorzystana także przez National Museum of Ireland podczas kampanii przed referendum mającym zadecydować o liberalizacji prawa aborcyjnego w $2018 \mathrm{r}$. Muzeum pozyskało do swojej kolekcji przypinki (badże), plakaty, transparenty, a nawet elementy ubioru, na których manifestujący zwolennicy i przeciwnicy liberalizacji prawa wypisywali swoje hasła ${ }^{19}$. W tym kontekście warto wspomnieć również o wystawie „Disobedient objects” (dosłownie „Obiekty nieposłuszne”), prezentowanej w V\&A Museum na przełomie 2014 i 2015 r. Było to połączenie retrospektywnej wystawy historycznej (pojawiły się między innymi muzealia dokumentujące masowe strajki polskiej Solidarności w latach osiemdziesiątych XX w.) z wątkami ówczesnych protestów społecznych w różnych częściach świata ${ }^{20}$. Wystawa ta wywołała ożywioną dyskusję wokół tematu „muzeów zaangażowanych” i ,aktywnych” (,activist museum”), której prezentacja wykracza jednak poza założenia badawcze niniejszego artykułu.

W Polsce zima na przełomie 2020 i 2021 r. była nie tylko czasem zmagań z rosnącą liczbą zakażeń wirusem SARS-CoV-2, ale także masowych protestów organizowanych przez Ogólnopolski Strajk Kobiet. Muzeum Gdańska ogłosiło zbiórkę transparentów, flag i zdjęć związanych z manifestacjami ${ }^{21}$. Lokalne media i serwisy miejskie w listopadzie $2020 \mathrm{r}$. informowały o pierwszych przekazanych obiektach, a w marcu 2021 r. o satysfakcjonujących wynikach kilkumiesięcznej zbiórki. W jednym z artykułów prasowych dyrektor Muzeum Gdańska dr hab. Waldemar

18 „Współistnienie 30 VI 2021 - 24 IV 2022”, Muzeum Krakowa, https://muzeumkrakowa.pl/ wystawy/wspolistnienie, dostęp 14 VI $2021 \mathrm{r}$.

19 Brenda Malone, „Rapid Response Collecting and the Irish Abortion Referendum”, Science Museum Group Journal 14 (2020), http://dx.doi.org/10.15180/201401.

20 Matt Smith, Catherine Flood, „Disobedient Curating: Matt Smith Speaks with Catherine Flood”, Art Journal 76, issue 3/4 (Fall/Winter 2017): 92-100; Mary Elizabeth Williams, „A Noble Balancing Act: Museums, Political Activism and Protest Art”, Museum International 69, issue 3/4 (2017): 66-75.

${ }^{21}$ Także na oficjalnej stronie internetowej Muzeum Gdańska: „Jak przekazać swoje transparenty, zdjęcia i filmy do Muzeum Gdańska?, Muzeum Gdańska, https://muzeumgdansk.pl/wydarzenia/ szczegoly/news/strajk-kobiet/, dostęp 14 VI 2021 r. 
Ossowski w ten sposób przedstawił politykę gromadzenia zbiorów w podległej mu instytucji:

Do naszych zbiorów otrzymaliśmy pamiątki po śp. Pawle Adamowiczu, czy maseczki z czasów tegorocznej pandemii, które zasłaniały w tym roku twarze [pomników przyp. M.P.] Neptuna i Jana III Sobieskiego [...] Masowość i powszechność obecnych protestów, tłumy gdańszczanek i gdańszczan, którzy wyszli na ulice, pomimo że jest wydarzeniem toczącym się na naszych oczach, to już również część historii życia naszej lokalnej społeczności [...] Co nasze pokolenia będą opowiadać o tych strajkach za 50, za 100 i więcej lat? Czy zachowają się po nich materialne ślady? Kto ma je zachować? Odpowiedzi na pierwsze dwa pytania poznamy tylko wtedy, jeśli do muzeów trafią pamiątki takie jak plakaty, afisze, transparenty, czy zdjęcia, a nawet filmy z protestów, które przekazane są przez ich autorów do muzeów - skarbnic naszej wiedzy o przeszłości i instytucji chroniących te świadectwa ${ }^{22}$.

Choć RRC nie zostało tu przywołane expressis verbis, to słowa dyrektora Muzeum Gdańska uznać można za trafną charakterystykę tej praktyki muzealnej. Muzeum Gdańska ogłosiło zbiórkę transparentów Strajku Kobiet, a Muzeum Sztuki Nowoczesnej w Warszawie zostało spontanicznie „wciągnięte” do akcji przez studentki i studentów Akademii Sztuk Pięknych (dalej: ASP). W październiku 2020 r. po jednej z manifestacji Strajku Kobiet młodzi ludzie nawoływali do stworzenia wokół Muzeum instalacji „Las transparentów”. Różne media przytaczały tę samą wypowiedź dyrektor Muzeum Joanny Mytkowskiej: „To akcja spontaniczna, muzeum jej nie organizuje [...] Z pewnością skorzystamy z okazji, żeby jako muzeum zarchiwizować historię protestów"23. Akcja rozpoczęta przez społeczeństwo (studentów i studentki ASP), będąca wyrazem pewnych oczekiwań wobec instytucji muzealnej, na którą Muzeum Sztuki Nowoczesnej w Warszawie odpowiedziało w czasie rzeczywistym, jest interesującym przyczynkiem do toczącej się obecnie dyskusji nad społeczną rolą i definicją muzeum.

Jeśli zastanowić się nad niewielką popularnością RRC w Polsce, to przede wszystkim zwracają uwagę ograniczenia formalne. Opieka nad zbiorami jest jedną z najbardziej sformalizowanych dziedzin aktywności muzeów - właściwa inwentaryzacja jest uregulowana większą liczbą przepisów niż na przykład szeroko rozumiana edukacja muzealna. Najważniejsze jej elementy są wskazane już na poziomie ustawy (Rozdział 4 Ustawy z dnia 21 listopada 1996 r. o muzeach), kolejne - w szczegółowym

22 Joanna Wiśniowska, „Muzeum Gdańska zbiera transparenty ze Strajku Kobiet. Za 100 lat mogą być cenne", internetowe wydanie Gazety Wyborczej Trójmiasto, 2 XI 2020 r., https://trojmiasto.wyborcza.pl/trojmiasto/7,35612,26457373, muzeum-gdanska-zbiera-transparenty-ze-strajku-kobiet-za-100.html, dostęp 14 VI $2021 \mathrm{r}$.

23 „Las Transparentów. Niezwykła wystawa powstała po proteście”, 31 X 2020 r., https://wiadomosci. onet.pl/warszawa/strajk-kobiet-las-transparentow-niezwykla-wystawa-powstala-po-protescie/ 0bq3sch, dostęp 14 VI 2021 r. Por. interesujący tekst publicystyczny Marty Mazuś w tygodniku Polityka: Marta Mazuś, fot. Stanisław Ciok, „Muzeum dnia codziennego”, Polityka 12 (2021): 92-97. 
Rozporządzeniu Ministra Kultury z dnia 30 sierpnia 2004 r. w sprawie zakresu, form i sposobu ewidencjonowania zabytków w muzeach. Część muzeów przygotowuje także wieloletnie strategie pozyskiwania i gromadzenia zbiorów. Ograniczeniem mogą być również kwestie tyleż prozaiczne, co zasadnicze: powierzchnia magazynowa i budżet. Kolejnym ważnym elementem mogącym wywierać wpływ na częstotliwość stosowania RRC jest profil wykształcenia profesjonalistów opiekujących się zbiorami muzealnymi. Często są to historycy, historycy sztuki lub absolwenci specjalistycznych studiów z zakresu konserwacji zabytków. Tymczasem zjawiska zachodzące we współczesnym świecie są domeną badawczą socjologów.

Powyżej wymieniono przykłady aktywności muzeów z Krakowa, Gdańska i Warszawy. Dlaczego zatem w tytule artykułu zostało zasugerowane niestosowanie RRC? Obecnie w Polsce jest 938 muzeów ${ }^{24}$. Wydaje się - nawet bez wyczerpujących badań ankietowych i statystycznych - że stosunkowo niewielka liczba muzeów już w trakcie trwania pandemii na bieżąco dokumentowała wydarzenia, zbierając materialne świadectwa czasu zarazy. Jak zatem polskie muzea towarzyszyły lokalnym (i ponadlokalnym) społecznościom w tym trudnym czasie?

\section{Aktywność online: towarzyszenie społecznościom}

Muzea były tymi instytucjami, które już w marcu i kwietniu 2020 r. - a więc podczas pierwszego lockdownu w Polsce - aktywnie włączyły się w udostępnianie w internecie materiałów, które miały pomóc spędzać czas podczas domowej kwarantanny (akcja \#zostanwdomu). Część z nich została zebrana z inicjatywy Narodowego Instytutu Muzealnictwa i Ochrony Zbiorów na portalu muzealnictwo.com ${ }^{25}$. Powstały już pierwsze publikacje, w których przeczytać można o przeniesieniu działalności muzeów online: czy to w kontekście globalnym ${ }^{26}$, czy też w tekstach prezentujących szczegółowo funkcjonowanie jednej instytucji ${ }^{27}$. W niniejszym artykule warto natomiast zwrócić uwagę na swego rodzaju gradację działań online $e^{28}$. W pierwszych dniach i tygodniach całkowicie nowej sytuacji muzea przede wszystkim

${ }^{24} 135$ muzeów rejestrowanych i 938 muzeów w ogóle - według Państwowego Rejestru Muzeów i Wykazu muzeów dostępnych w Biuletynie Informacji Publicznej Ministerstwa Kultury, Dziedzictwa Narodowego i Sportu, https://bip.mkdnis.gov.pl/pages/rejestry-ewidencje-archiwa-wykazy/rejestry-muzeow.php, dostęp 15 VI $2021 \mathrm{r}$.

25 „Muzea zapraszają do sieci”, Muzealnictwo.com, http://muzealnictwo.com/2021/03/muzea-zamkniete-ale-zapraszaja-do-sieci/, dostęp 29 VII 2021 r.

${ }_{26}$ Mateusz Bieczyński, „Szok kulturowy - działalność muzeów w czasie pandemii”, Muzealnictwo 62 (2021): 23-29, DOI: 10.5604/01.3001.0014.8573.

27 Bartłomiej Kłusek, „Funkcjonowanie Muzeum Niepodległości online w okresie lockdownu instytucji kultury", Niepodległość i pamięć 71, nr 3 (2020): 131-149.

28 Aktywność muzeów w sieci była na tyle popularna, w mniejszym lub większym stopniu praktykowana w niemal wszystkich muzeach, że w tej części tekstu rezygnuję (z jednym wyjątkiem) z podawania konkretnych przykładów z poszczególnych muzeów. 
udostępniały online posiadane już materiały (np. nagrania ze zrealizowanych niegdyś wydarzeń), co wpisywało się w ogólnopolską akcję udostępniania spektakli czy filmów do oglądania w domu. Gdy stało się jasne, że zasady dystansu społecznego i izolacji będą potrzebne o wiele dłużej, zaczęto produkować nowe materiały, „skrojone” do wymagań chwili. Przybierały one bardzo urozmaiconą formę i były udostępniane za pomocą różnorodnych platform i kanałów komunikacji. Nadal większość z nich zakładała jednak bierność odbiorcy (który np. ogląda, słucha lub czyta przygotowane wcześniej przez muzealników materiały). Część muzeów prowadziła (np. za pomocą Facebooka) relacje na żywo z wydarzeń realizowanych w muzeum bez udziału zwiedzających. Takie rozwiązanie można określić mianem pośredniego. Możliwość umieszczania komentarzy tekstowych podczas trwania transmisji z jednej bowiem strony umożliwia wyrażenie opinii $w$ trakcie wydarzenia, równocześnie jednak nie zakłada równorzędnego statusu nadawcy i odbiorcy. Niektóre muzea zdecydowały się iść krok dalej i zaczęły wykorzystywać w kontakcie ze swoimi „gośćmi” i „zwiedzającymi” rozwiązania informatyczne wykorzystywane w pracy i nauce zdalnej (np. Zoom). Takie spotkanie zakłada aktywność odbiorcy, który w czasie rzeczywistym uczestniczy w muzealnej dyskusji, spotkaniu autorskim lub oprowadzaniu kuratorskim. Niestety, właśnie te rozwiązania były i są najrzadsze. Choć wykracza to poza założenia badawcze niniejszego tekstu, warto postulować przeprowadzenie badań nad aktywnością polskich muzeów w trakcie pandemii w oparciu o naukę o komunikowaniu. Komunikologia podkreśla rolę sprzężenia zwrotnego między nadawcą a odbiorcą komunikatu. W działaniach muzeów w trakcie kolejnych lockdownów występowały cechy komunikacji masowej (duże grupy anonimowych odbiorców), ale także komunikowania medialnego jako rodzaju komunikowania interpersonalnego (np. spotkania online z użyciem połączeń video $)^{29}$.

Analogiczną gradację działalności muzeów w sieci można odnieść do edukacji muzealnej, zarówno tej skierowanej do odbiorcy indywidualnego (np. rodzin z dziećmi), jak i oferty edukacyjnej dla szkół. Tylko część muzeów wprowadziła do swojej oferty zajęcia online w czasie rzeczywistym ${ }^{30}$. Ich wielką zaletą jest wykorzystywana w trakcie pandemii możliwość uczestniczenia w zajęciach

29 Zob. np. Marek Sokołowski, (R)ewolucja w komunikacji. Wprowadzenie do medioznawstwa (Warszawa: Wydawnictwo Comandor, 2010), 41-42.

30 Por. Magdalena Pasternak-Zabielska, Raport z badania Instytucje kultury w okresie COVID-19. Muzealne strategie docierania do widzów (Warszawa: Narodowy Instytut Muzealnictwa i Ochrony Zbiorów, 2021), 14: „Od marca 2020 roku większość działów edukacji przeniosła swoją aktywność do świata wirtualnego. (40\%) z nich prowadzi ją w czasie rzeczywistym w formie webinarium korzystając z platformy Zoom (35,48\%), MS Teams (17,47\%) lub Google Meet (12,90\%)". Wskazana liczba $40 \%$ wydaje się znaczna, choć równocześnie zastrzec trzeba, że nie były to obowiązkowe badania wszystkich muzeów w Polsce, lecz dobrowolnie wypełniana ankieta. Jak wyjaśniają organizatorzy: „Badanie zostało zrealizowane $\mathrm{w}$ technice ankiety internetowej na przełomie listopada i grudnia 2020 roku na grupie 53 instytucji muzealnych", Pasternak-Zabielska, Raport, 4. 
organizowanych przez muzeum spoza swojego miasta czy regionu ${ }^{31}$. Jest to jedno z tych rozwiązań wypracowanych $\mathrm{w}$ dobie pandemii, które warto zachować po zniesieniu wszelkich obostrzeń sanitarnych.

Przedstawiając z optymizmem aktywność online polskich muzeów w trakcie pandemii, trzeba jednak pamiętać o zjawisku wykluczenia cyfrowego. Nie każdy z potencjalnych odbiorców i uczestników oferty muzeów ma sprzęt elektroniczny (komputery, urządzenia mobilne) oraz dostęp do internetu i nie każdy ma wystarczające kompetencje - nawet posiadając odpowiedni sprzęt - aby korzystać z oferty online. Najciekawsze i najbardziej wartościowe spotkania online, czyli te dziejące się w czasie rzeczywistym, paradoksalnie mogą być jeszcze trudniejsze dla osób, które na co dzień nie pracują za pośrednictwem internetu (np. seniorów).

\section{Zakończenie: wpływ pandemii na przemiany praktyki i teorii muzeologii}

Przytłaczająca większość polskich muzeów nie podjęła działań zmierzających do przygotowania już w 2020 lub 2021 r. wystaw nawiązujących do aktualnych przeżyć ludzi zmagających się z zagrożeniem epidemicznym. Nie włączano również na bieżąco do kolekcji muzealnych obiektów bezpośrednio związanych z pandemią. Zapewne z czasem takich materialnych świadectw i wystaw w ujęciu historycznym będzie coraz więcej - ale działanie retrospektywne nie jest już częścią RRC ${ }^{32}$.

Równocześnie muzealnicy włożyli wiele wysiłku i inwencji w towarzyszenie społeczeństwu w czasie izolacji poprzez działalność online. Przed pandemią zarówno w światowej, jak i polskiej literaturze przedmiotu zastanawiano się nad tym, czym jest muzeum wirtualne, i debatowano nad stopniem wirtualizacji muzeów działających stacjonarnie w swoich siedzibach ${ }^{33}$. Mimo wyraźnej potrzeby powrotu do bezpośrednich kontaktów społecznych po okresie izolacji

31 Muzeum Narodowe w Warszawie zachęca do uczestnictwa również grupy polonijne z całego świata: „LEKCJE POLECANE SZCZEGÓLNIE SZKOŁOM POLONIJNYM: Rejs po Wiśle, czyli artystyczna wyprawa po polskich miastach i miasteczkach, Wyprawa w góry, czyli dlaczego Tatry zachwyciły artystów", MNW, https://www.mnw.art.pl/edukacja/lekcje-muzealne-on-line/, dostęp 15 VI $2021 \mathrm{r}$.

32 Por. Elizabeth Mariano Mubarek, „The End of Passive Collecting: The Role and Responsibility of Archivists in the COVID-19 Era”, Collections: A Journal for Museum and Archives Professionals 17, issue 2 (2021): 1: „Set against the backdrop of the COVID-19 pandemic, this article argues that it is imperative that archivists be strongly attuned to current events, both locally and worldwide, so as to best serve their communities. Historic events should not necessarily be documented and recorded retroactively; rather, professional archivists have a responsibility to actively spearhead initiatives to collect contemporaneous documents, ephemera, and artifacts that record history as it is occurring, thus offering more personalized insights into the firsthand impact of significant events on daily life”.

33 Zob. Dorota Folga-Januszewska, „Muzeum: definicja i pojęcie. Czym jest muzeum dzisiaj?”, Muzealnictwo 49 (2008): 200-203. 
najprawdopodobniej część rozwiązań wypracowanych w dobie pandemii zostanie w muzeach na dłużej. Doświadczenie lat 2020-2021 wpłynęło na teorię muzeologii: po tym okresie trudniej ponawiać pytania, czy muzeum wirtualne to nadal muzeum ${ }^{34}$. Nawet jeśli takie pytanie wciąż jest zasadne w przypadku muzeum funkcjonującego wyłącznie w internecie (a więc bez siedziby stacjonarnej), to z całą pewnością znacznej (nieodwracalnej?) przemianie uległ kontekst organizacyjny, administracyjny i społeczny, w jakim obecnie szukamy odpowiedzi.

Postulując szersze stosowanie RRC, warto wskazać na wpisywanie się tego sposobu działania w przemiany zachodzące w muzealnictwie. W wielu muzeach gabloty zostały zamienione na wystawy narracyjne, zmieniła się rola gościa muzeum ( $\mathrm{z}$ widza na uczestnika kultury), w definicji muzeum pojawiły się także określenia „rozrywka” i „przyjemność”35. W tym kontekście zwraca uwage korelacja pomiędzy zastosowaniem w praktyce RRC przez Muzeum Gdańska (opisane powyżej) a podejmowaniem przez nie szerszej refleksji nad przemianami i funkcjami muzeum. W 2020 r. w Muzeum Gdańska prezentowana była wystawa „Co (się na) daje (do) muzeum?”, której towarzyszył katalog pod tym samym tytułem ${ }^{36}$.

Organizacje zrzeszające muzea oraz agendy do spraw kultury już w trakcie pandemii publikowały raporty zawierające analizy bieżącej sytuacji ${ }^{37}$. W $2021 \mathrm{r}$. opublikowano pierwsze bardziej całościowe analizy działalności muzeów w trakcie pandemii oraz badania statystyczne. Na ich podstawie można wnioskować, że przenoszenie działalności do internetu wydaje się być dominującym remedium na czas kryzysu. W wielu takich publikacjach czy raportach nie wspomina się o RRC i możliwościach, jakie niesie ze sobą ten sposób działania. Warto zatem upowszechniać wiedzę o RRC i różnorodnych sytuacjach na całym świecie, w których muzea z powodzeniem zastosowały ten sposób tworzenia kolekcji w żywym dialogu ze społeczeństwem.

${ }^{34}$ Zob. interesujące studium przypadku: M. Pałasz, „Czy muzeum wirtualne jest muzeum? Przypadek Muzeum Erotyzmu”, Rocznik Muzeum Wsi Mazowieckiej w Sierpcu 6 (2015): 27-42.

35 Przemiany w muzeologii posiadają obszerną literaturę przedmiotu w skali globalnej. Z polskich prac jako punkt wyjścia przedstawić można publikacje z serii Muzeologia, takie jak m.in. Mirosław Borusiewicz, Nauka czy rozrywka? Nowa muzeologia w europejskich definicjach muzeum (Kraków: Wydawnictwo Universitas, 2012); Dorota Folga-Januszewska, Muzeum. Fenomeny i problemy (Kraków: Wydawnictwo Universitas; Warszawa: Muzeum Pałacu Króla Jana III w Wilanowie, 2015); Muzeum i zmiana. Losy muzeów narracyjnych, red. Paweł Kowal, Karolina Wolska-Pabian (Warszawa: Muzeum Powstania Warszawskiego; Kraków: Wydawnictwo Universitas, 2019).

36 Anna Frąckowska, Andrzej Hoja, Mateusz Jasik, Dorota Powirska, Co (się na) daje (do) muzeum? (Gdańsk: Muzeum Gdańska, 2020).

37 Zestawienie najważniejszych raportów (m.in. UNESCO) w Bieczyński, „Szok kulturowy”; por. Pasternak-Zabielska, Raport z badania. 
Michalina Petelska

\section{Polish museums during the COVID-19 pandemic: Online activity and (non)application of Rapid Response Collecting}

The subject of this article is Rapid Response Collecting (RRC) as one of the ways in which museums can operate in exceptional situations. Between 2020 and 2021, in Poland and all over the world, curators resorted to RRC in order to document - in live dialogue with society - the pandemic and social protests. The subject of RRC is barely present in the subject literature. This article gathers English-language scholarly literature from the USA and various European countries, and it analyzes cases of applying RRC in Polish museums during the COVID-19 epidemic. From the pandemic's first weeks, numerous journalistic pieces (and sometime scholarly ones too) - about online activities of museums and other institutions have been published. Internet activities are seen as the first, most obvious, and even universal "cure" for all the difficulties of times of plague. The aim of this article is to present another way in which museums can react to dynamic changes in the surrounding world. In this article, RRC is also presented in the context of transformations taking place in the theory and practice of museum studies in the last few decades. The application of RRC is part of museum activity implemented according to the latest international definitions of a museum, both those in operation and those recommended. 